\title{
Environmental Factors affecting the Bionomics of An. culicifacies and Malaria Endemicity
}

\author{
Asima Tripathy* \\ Post Graduate Department of Zoology, Bhadrak Autonomous College, Bhadrak -756100, Odisha, India; \\ asimatripathy09@gmail.com
}

\begin{abstract}
Objective: To study the effect of environmental parameters like humidity, rainfall and temperature on the dynamics of vectorial competence of An. culicifacies. Methods: Epidemiological data and climatological data were collected from state Govt. (Odisha). And the mosquito bionomics was studied in laboratory regression test of PMHD of An. culicifacies, SPR in relation to mean rainfall, mean humidity and mean temperature were done. Applications/Improvements: Linear regression test of the afore-mentioned and in addition to them mean humidity and SPR, mean humidity and PMHD showed positive correlation. Linear regression test of PMHD An. culicifacies and SPR of the study districts showed positive correlation with correlation coefficient value $r^{2}=0.88$ and $p$ value $=0.0006$. Conclusion: The results proved the effect of the above mentioned parameters in malaria transmission by favoring vector biology and thus malaria endemicity.
\end{abstract}

Keywords: Anopheles Culicifacies, Climatic Factors, Malaria Endemicity, Vector Bionomics, Vectorial Competence

\section{Introduction}

Malaria is a public health problem in India and creates severe roadblocks to its development ${ }^{\underline{1}}$. An. culicifacies is a known rural malaria vector in India ${ }^{2,3}$. India's contribution to the global total of 2-3 million malaria every year is about $60-70 \%$. Irrespective of climatic variation An. culicifacies is widely distributed in most states of India and has been recorded in all mainland zones including Kashmir and high elevations in the Himalayas (up to 3000 meters) except islands of Lakshadweep and Andaman and Nicobar. It also extends beyond India's boundaries to Pakistan, Afghanistan, Iran, Yemen and Ethiopia to the west; to Bangladesh, Thailand, Myanmar, Laos and upto Vietnam to the East; to Nepal and Southern China in the North and upto Sri Lanka in the South $\frac{5-7}{2}$. It is the most important vector in plains of rural India contributing $60-70 \%$ of reported cases annually $\frac{7,8}{.}$. It is recognized as a primary vector of malaria, a disease of great socioeconomic significance, in different areas of the world? Bionomics is that part of biology which deals with the relationships of a given species and its environment.
The bionomics of Anophelines include the development of immature stages i.e. eggs, larvae and pupae as well as the life of the adults under the influences exercised by the environmental conditions. Behavior is the result of the interaction of genetic factors, which govern the basic lines of behavior and ecological factors which may produce different types of reaction in a population having the same genetic characteristics.

Among the ecological factors, the phonological (study of seasonal periodic biological events) one is of considerable importance. For example, the ability of mosquitoes to breed in fresh or salt water or both is controlled by genetic factors. Host preference seems to be governed by genetic factors also, but the intensity of feeding on a certain host may vary from place to place and even from day to day, not only with the availability of hosts, but also with the changes in meteorological conditions. The speed of the development of the mosquitoes is dependent mainly on climatic factors.

Climatic change may be natural and human caused and it includes regional weather variations, temperature, precipitation and humidity. These changes influence

${ }^{*}$ Author for correspondence 
longevity development of the vector, pathogen development, distribution and abundance of natural vertebrate hosts, duration of the aquatic stages, the speed of blood digestion and maturation of the ovaries, the frequency of feeding, vector habitat and naturally the disease transmission dynamics and ultimately influencing the vectorial capacity of the vector.

The Anopheline species is regarded as endophilic when largely found resting indoors or exophilic when largely found resting outdoors, although partial exophily has also been observed. Selection of the resting habitats is much influenced by the temperature and humidity of favorable resting places and human habitats.

Humidity is the limiting factor in the distribution and longevity. Forest species are more susceptible to humidity changes than those living in areas with a dry climate. During dry weather, indoor mosquitoes will concentrate in those housed or other indoor resting places where the microclimate offers a favorable humidity. Outdoorresting mosquitoes will rest in the vegetation near the ground when it is dry. During the day mosquitoes rest inactive in cooler places. At dusk, when the temperature drops and the humidity increases, the mosquitoes suddenly become activated.

The effect of rainfall varies according to its amount and the features of the terrain. Repeated rains cause severe flooding, resulting in temporary flushing out of the breeding places. Consequently, the breeding of a vector population is greatly reduced but it will soon be re-established when normal conditions are restored. Moderately frequent rainfall but with fairly long periods of sunshine will increase the opportunity of prolific breeding.

Though a lot of work is available on the effect of climatic factors on transmission of malaria in other countries, very little is available about the same in India ${ }^{10-18}$. Thus, the environmental factors like rainfall, temperature and humidity are of great importance for the study of dynamics of An. culicifacies and its vectorial competence.

\section{Methodology}

\subsection{Climatological Data}

The data on relative humidity, rainfall and temperature of the relevant study districts were obtained from metrological department, Government of India.

\subsection{Mosquito Collection}

An entomological survey was done in the district including both forested and non forested areas. In the morning hours between $06.00 \mathrm{am}$ and $9.00 \mathrm{am}$, indoor resting mosquito samples were collected from houses using mouth aspirators. Identification of species was done according to Christophers' taxonomic keys ${ }^{19}$. The entomological data were taken for calculation of the entomological indices. The PMHD of An. culicifacies was then calculated as the number of mosquitoes per man per hour.

Thus PMHD $=$ Number of mosquitoes collected (particular species)/(number of persons involved in collection) $\mathrm{x}$ (actual time spent in collection).

\subsection{Epidemiological Data}

The epidemiological data of the study districts were duly collected from the State Government for analysis.

\subsection{Study Period}

Study was performed from 2006 to 2008.

\subsection{Statistical Analysis}

A linear regression test was done of An. culicifacies PMHD and SPR, mean rainfall and PMHD and SPR, mean humidity PMHD and SPR as also mean temperature PMHD and SPR were done.

\section{Results}

The data on PMHD and the SPR of the An. culicifacies in the study districts are depicted in the following table. Highest PMHD was found in Dhenkanal followed by Angul, Keonjhar, Ganjam, Nayagarh, Khurda, Puri, Jagatsingpur (Table 1). However, in forested districts higher PMHD of An. culicifacies is found. The correlation of PMHD of An. culicifacies and SPR of the respective study areas showed directly proportional relationship $(\mathrm{P}<0.05)$ i.e. larger the PMHD of the species more is the SPR.

The mean rainfall, mean maximum temp, mean minimum temp and the mean humidity of 2006, 2007 and 2008 are depicted in the Table 2. There is an increase in all three parameters from 2006 to 2008 in majority of the study districts.

The SPR data of coastal and forested districts are shown in Figure 1. Low SPR is noted in the coastal districts as 
compared to the forested districts. However, among the forested districts higher SPR was seen in Angul, Dhenkanal and Keonjhar; intermediate values of SPR were observed in Ganjam, Nayagarhand Khurda.

The comparative PMHD data showed that it is low in the coastal districts as compared to the forested districts. However, among the forested districts higher PMHD was seen in forested districts (Keonjhar, Anugul and Dhenkanal). Intermediate PMHD was observed in the coastal districts (Nayagarh, Ganjam and Khurda) (Figure 2).

The SPR and respective PMHD of An. culicifacies for three consecutive years 2004, 2005, 2006 are given in the Table 3, which showed a direct positive correlation between PMHD of An. Culicifacies with higher SPR of all the districts. The mean of the climatic factors are compared with the PMHD and SPR in Table 3 to see if these environmental factors affecting the vector bionomics and malaria endemicity of the study area.

Table 1. PMHD of An. culicifacies and SPR of the study areas (2008)

\begin{tabular}{|l|c|c|}
\hline Study areas & $\begin{array}{c}\text { PMHD of An. } \\
\text { culicifacies }\end{array}$ & $\begin{array}{c}\text { SPR of the study } \\
\text { districts }\end{array}$ \\
\hline Khurda & 3 & 3.86 \\
\hline Dhenkanal & 7.16 & 12.84 \\
\hline Nayagarh & 5.43 & 6.31 \\
\hline Puri & 3 & 0.4 \\
\hline Ganjam & 5.92 & 6.12 \\
\hline Jagatsingpur & 2.46 & 0.8 \\
\hline Angul & 6.8 & 12.5 \\
\hline Keonjhar & 6.56 & 10 \\
\hline
\end{tabular}

Table 2. Meteorological data recorded in eight endemic districts of Odisha

\begin{tabular}{|l|c|c|c|c|c|c|c|c|c|c|c|c|c|}
\hline \multirow{2}{*}{ Area } & \multicolumn{9}{|c|}{ Mean rainfall } & \multicolumn{3}{c|}{ Mean of max temp } & \multicolumn{3}{c|}{ Mean of min temp } & \multicolumn{3}{c|}{ Mean of humidity } \\
\cline { 2 - 14 } & 2006 & 2007 & 2008 & 2006 & 2007 & 2008 & 2006 & 2007 & 2008 & 2006 & 2007 & 2008 \\
\hline Coastal district & 129.7 & 147.2 & 169.7 & 37.08 & 36.81 & 35.2 & 19.71 & 18.44 & 20.9 & 72 & 71.96 & 79.88 \\
\hline Jagatsingpur & 86.82 & 98.96 & 161 & 36.75 & 39.71 & 33.9 & 14.75 & 16.78 & 20.43 & 63.96 & 61.13 & 78.17 \\
\hline Puri & \multicolumn{10}{|c|}{} \\
\hline Forested districts \\
\hline Dhenkanal & 87.33 & 145.1 & 116.4 & 36.75 & 39.7 & 38.1 & 18.45 & 16.78 & 15.9 & 63.96 & 61.125 & 58.25 \\
\hline Nayagarh & 102.1 & 145.9 & 115 & 37.1 & 36.6 & 37.1 & 14.45 & 19.3 & 19.49 & 71.13 & 74.41 & 72.46 \\
\hline Ganjam & 71.96 & 94.62 & 103.3 & 34.93 & 33.68 & 34.6 & 19.43 & 20.65 & 20.23 & 78.25 & 78.13 & 77.75 \\
\hline Angul & 111.7 & 141.9 & 112 & 36.75 & 39.71 & 38.1 & 14.45 & 16.78 & 15.9 & 63.96 & 61.13 & 58.25 \\
\hline Keonjhar & 90.5 & 134.9 & 129.3 & 35.4 & 34.73 & 35.2 & 15.32 & 15.58 & 15.93 & 59.1 & 64.83 & 65.5 \\
\hline Khurda & 91.66 & 119.7 & 140.4 & 37.1 & 36.6 & 37.1 & 18.45 & 19.3 & 19.49 & 71.13 & 74.41 & 72.46 \\
\hline
\end{tabular}

Table 3. Mean rainfall, temperature, humidity and respective SPR of the study districts

\begin{tabular}{|l|c|c|c|c|c|}
\hline \multirow{2}{*}{ Area } & \multicolumn{2}{|c|}{ Average rainfall temperature and humidity of 2004-2006 } & \multirow{2}{*}{ Mean SPR } & \multirow{2}{*}{ PMHD } \\
\cline { 2 - 4 } & Mean rainfall/ month & Mean Temperature & Mean humidity & & \\
\hline Khurda & 117.23 & 25.3 & 72.67 & 3.86 & 2.8 \\
\hline Dhenkanal & 116.28 & 23.6 & 61.11 & 12.84 & 6.4 \\
\hline Nayagarh & 121 & 25.3 & 72.67 & 6.31 & 5.2 \\
\hline Puri & 115.6 & 23.7 & 67.75 & 0.4 & 2 \\
\hline Ganjam & 89.94 & 25.2 & 78.04 & 6.12 & 5.98 \\
\hline Jagatsingpur & 148.88 & 24.84 & 74.61 & 0.8 & 2.9 \\
\hline Angul & 121.89 & 23.6 & 61.11 & 12.5 & 6.5 \\
\hline Keonjhar & 118.21 & 22.2 & 63.14 & 10 & 6.32 \\
\hline
\end{tabular}




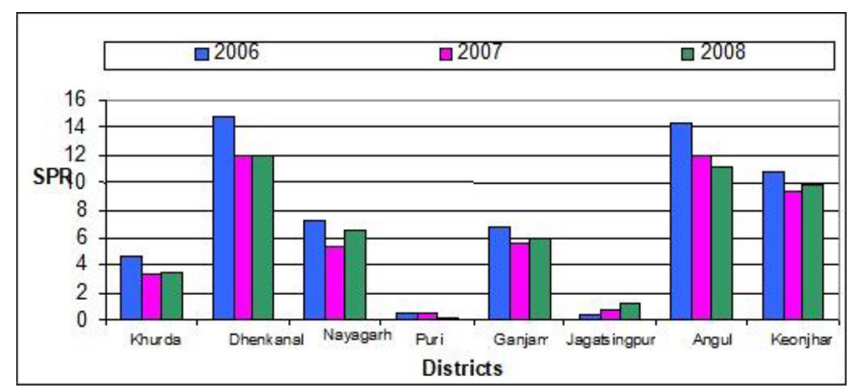

Figure 1. SPR in three different years in the study districts.

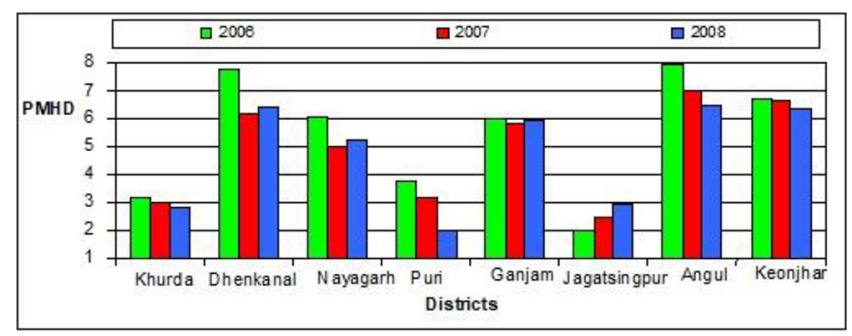

Figure 2. PMHD of An. culicifacies in three different years in the study districts.

\subsection{Statistical Analysis}

Linear regression test of PMHD An. culicifacies and SPR, mean rainfall PMHD and SPR, mean humidity SPR and PMHD, mean temperature PMHD and SPR, showed positive correlation. Linear regression test of PMHD An. culicifacies and SPR of the study districts has positive correlation with correlation coefficient value $r^{2}=0.88$, $\mathrm{p}$ value $=0.0006$. Other parameters did not show significant association in this study.

\section{Discussion}

There has been a prolonged duration study of the positive correlation between rainfall and malaria ${ }^{20-23}$ and in some other studies there was no strong correlation visible ${ }^{24,25}$. The role of climatic factors in malaria endemicity in high land areas shows that transmission of malaria involves complicated interactions among the different Plasmodium stratins, anopheline mosquitoes and humanoid hosts ${ }^{26}$. It is observed that the transmission fails to occur if the vector life span is less than the time required for the development of the pathogen to its virulent stage $\frac{16}{}$.

In addition to changes in the amount and the rate of transmission of vectors and parasites that are already there in a certain area, change of climate of the area can allow the introduction of different vectors and parasites that may be more efficient. Since P. malariae and P. ovale have longer extrinsic cycles, some mosquitoes have not the life span to transmit them. However, if environmental conditions change in ways that would increase the survival time of those mosquitoes, then they can transmit other species of malaria that were not present in that area before. The seasonal malaria peak is directly related to the rainfall peaks ${ }^{27}$.

A study in Quetta indicated that An. culicifacies appears mostly in April and May and increases greatly in June and July and then the decline starts mostly in September ${ }^{28}$. This indicates that An. culicifacies is not resistant to low temperatures. Its density has been correlated to temperature and also to humidity and rainfall, which played a positive role in the rising of the vector prevalence. The density of An. culicifacies was the maximum during summer, but incidence of malaria was at its lowest level during this season ${ }^{29}$.

Yet another study in Southern districts of Odisha State revealed that the high density could play a major role in transmission of malaria. Through infection rate was low $(1.39 \%)$ and it has poor anthropophagy but its high density was compensating towards its contribution towards malaria transmission ${ }^{30}$.

In the current study, the density of An. culicifacies is seen to be high in forest areas, but shows variations with climatic factors. Similar observation of increase of An. Culicifacies density was found in Mandala district, Madhya Pradesh, India ${ }^{31}$.

However, in Southern districts of Odisha, it was found that the density of An. culicifacies did not indicate any association with incidence of malaria ${ }^{30}$. However, they found higher density of An. culicifacies in some study districts with comparatively low incidence of malaria parasite where density of An. fluviatilis was high. A study in a malaria-prevalent area Sistanva Baluchestan province, south-east Islamic Republic of Iran has revealed low activity of An. culicifacies during cold winter and hot summer periods ${ }^{32}$.

However the other functional aspects (Anthropophilic nature, gonotropic cycle, sporozoite rate, biting habit, resting habit, breeding habit etc.) of bionomics of An. culicifacies with regard to the changes in climatic factors have not been touched upon. A detailed document to this by the author is in pipeline which will correlate the above aspects of vector bionomics (An. culicifacies) as climate is one of the major factors which affect the incidence of 
malaria. With rise of global temperature in twenty first century changes in distribution of vector and of prevalence are sure to occure? .

\section{Conclusion}

Climatic factors are found to have an impact on malaria transmission through their effect on the life span, capacity and virulence of the vector. An understanding of such effects is sure to help us design the eradication program in a more efficient manner in Odisha in particular and in general at other similar places also having similar climatic variations and geographic features.

\section{Acknowledgements}

The author thanks Dr. S. K. Kar, Director, Regional Medical Research Center (RMRC), Indian Council of Medical Research and Bhubaneswar for providing Institutional Support in conducting the statistical analysis and the Metrological Department, Bhubaneswar for providing the climatic data of the study districts during the period concerned. Also thanks author's colleague Dr. Rajat Kumar Pradhan for help in preparation and finalization of the article.

\section{Reference}

1. Sharma SK, Tyagi PK, Padhan K, Upadhyay AK, Haque MA, Nanda N, Joshi H, Biswas S, Adak T, Das BS, Chauhan VS, Chitnis CE, Subbarao SK. Epidemiology of malaria transmission in forest and plain ecotype villages in Sundargarh District, Orissa, India. Transactions of the Royal Society of Tropical Medicine and Hygiene. 2006; 100(10):917-25. PMid: 16697022. https://doi.org/10.1016/j. trstmh.2006.01.007

2. Ghosh SK, Tiwari S, Raghavendra K, Sathyanarayan TS, Dash AP. Observations on sporozoite detection in naturally infected sibling species of the Anopheles culicifacies complex and variant of Anopheles stephensi in India. Journal of Biosciences. 2008; 33(3):333-6. PMid: 19005232. https:// doi.org/10.1007/s12038-008-0052-5

3. Mishra AK, Chand SK, Barik TK, Dua VK, Raghavendra K. Insecticide resistance status in Anopheles culicifaciesin Madhya Pradesh, central India. Journal of Vector Borne Diseases. 2012; 49(1):39-41. PMid: 22585243.

4. Manonmani AM, Sadanandane C, Sahu SS, Mathivanan A, Jambulingum P. rDNA - ITS2-PCR assay for grouping the cryptic species on Anopheles culicifacies complex. (Diptera:
Culicidae). Acta Tropica.2007; 104(1):72-7.PMid:17709089 https://doi.org/10.1016/j.actatropica.2007.07.002

5. Nagpal BN, Sharma VP. Indian Anophelines. New Delhi: Oxford and IBH Publishing Co. Pvt. Ltd; 1995. p. 1-416.

6. World Health Organization, Regional Office for South-East Asia. Anopheline Species Complexes in South-East Asia. SEARO Technical Publication. 1998; 18:82-3.

7. Rao TR. The Anophelines of India. New Delhi: Indian Council for Medical Research; 1981.

8. Sharma VP. Re-emergence of malaria in India. Indian Journal of Medical Research. 1996; 103:26-45. PMid: 8926025.

9. Barik TK, Sahu B, Swain V. A review on Anopheles culicifacies: From bionomics to control with special reference to Indian subcontinent. Acta Tropica. 2009; 109(2):87-97. PMid: 19000647. https://doi.org/10.1016/j.actatropica.2008.09.017

10. Singh N, Sharma VP. Patterns of rainfall and malaria in Madhya Pradesh, central India. Annals of Tropical Medicine and Parasitology. 2002; 96(4):349-59. PMid: 12171616. https://doi.org/10.1179/000349802125001113

11. Loevinsohn ME. Climatic warming and increased malaria incidence in Rwanda. Lancet. 1994; 343(8899):714-8. https://doi.org/10.1016/S0140-6736(94)91586-5

12. Martens WJ. Climate change and malaria: Exploring the risks. Med War. 1995; 11(4):202-13. PMid: 8559118. https://doi.org/10.1080/07488009508409240

13. Bryan JH, Foley DH, Sutherst RW. Malaria transmission and climate change in Australia. The Medical Journal of Australia. 1996; 164(6):345-7. PMid: 8606659.

14. Lindsay SW, Birley MH. Climate change and malaria transmission. Annals of Tropical Medicine and Parasitology. 1996; 90(6):573-88. PMid: 9039269. https://doi.org/10.108 0/00034983.1996.11813087

15. Kilian AH, Langi P, Talisuna A, Kabagambe G. Rainfall pattern, El Nino and malaria in Uganda. Transactions of the Royal Society of Tropical Medicine and Hygiene. 1999; 93(1):22-3. https://doi.org/10.1016/S0035-9203(99) 90165-7

16. Reiter P. Climate change and mosquito-borne disease. Environmental Health Perspectives. 2001; 109(Sup 1): 141-61.

17. Hay SI, Cox J, Rogers DJ, Randolph SE, Stern DI, Shanks GD, Myers MF, Snow RW. Climate change and the resurgence of malaria in the East African highlands. Nature. 2002; 415(6874):905-09. PMid: 11859368 PMCid: PMC3164800. https://doi.org/10.1038/415905a

18. Peng BT, Tong S, Donald K, Parton KA Jinfa NT. Climatic variables and transmission of malaria: A 12-year data analysis in Shuchen County, China. Public Health Reports. 2003; 118(1):65-71. https://doi.org/10.1016/ S0033-3549(04)50218-2 
19. Christophers SR. The fauna of British India including Ceylon and Burma, Family Culicidae. Tribe Anophelini. Taylor and Francis: London. 1933; 5:1-371.

20. Clemesha WW. Brief account of the natural history of malaria in Ceylon. Ceylon Journal of Science. 1934; 3: 157-72.

21. Gill CA. Some points in the epidemiology of malaria arising out of the study of the malaria epidemic in Ceylon in 193435. Transactions of the Royal Society of Tropical Medicine and Hygiene. 1936; 29(5):427-66. https://doi.org/10.1016/ S0035-9203(36)90001-9

22. Rustomjee KJ. Observations upon the epidemiology of malaria in Ceylon. Colombo: Ceylon Government Press; Colombo. 1944. p. 1-32.

23. Mendis C, Gamage-Mendis AC, De Zoysa AP, Abhayawardena TA, Carter R, Herath PR, Mendis KN. Characteristics of malaria transmission in Kataragama, Sri Lanka: A focus for immuno-epidemiological studies. American Journal of Tropical Medicine and Hygiene. 1990; 42(4):298-308. PMid2184688. https://doi.org/10.4269/ ajtmh.1990.42.298

24. Van der Hoek W, Konradsen F, Perera D, Amerasinghe PH, Amerasinghe FP. Correlation between rainfall and malaria in the dry zone of Sri Lanka. Annals of Tropical Medicine and Parasitology. 1997; 91(8):945-9. PMid: 9579215. https://doi.org/10.1080/00034989760347

25. De Alwis R, Wijesundere A, Ramasamy MS, Ramasamy R. Epidemiology of malaria in Aralaganvila in the Polonnaruwa district. Ramasamy R, ed. Current status of malaria research in Sri Lanka. Kandy: Institute of Fundamental Studies; 1990. p. 80-4.

26. Zhou G, Minakawa N, Githeko AK, Yan G. Association between climate variability and malaria epidemics in the East African highlands. Proceedings of the National Academy of Sciences of the USA. 2004; 101(8):2375-80. PMid: 14983017 PMCid: PMC356958. https://doi.org/10.1073/ pnas.0308714100

27. Briet OJT, Gunawardena DM, Van der Hoek W, Amerasinghe FP. Sri Lanka malaria maps. Malaria Journal. 2003; 2:22-31. PMid: 12914667 PMCid: PMC183859. https://doi.org/10.1186/1475-2875-2-22

28. Mansoor A. Climatic changes and natural population of Anopheles species in Quetta Valley. Journal of Medical Sciences. 2005; 5(4):298-302. https://doi.org/10.3923/jms. 2005.298.302

29. Prasad A, Mathur P, Srivastava M, Sharma E, Parveen A, Kumar D. Ecology and behavior of Anopheles culicifaciessensulato (s.l.) - A general review. International Journal of Current Research and Academic Review. 2015; 3(5):227-41.

30. Sahu SS, Gunasekaran K, Krishnamoorthy N, Vanamail P, Mathivanan A, Manonmani A, Jambulingam P. Bionomics of Anopheles fluviatilis and Anopheles culicifacies (Diptera:Culicidae) in relation to malaria transmission in East Central India. Journal of Medical Entomology. 2017; 54(4):821-30. PMid: 28399290 PMCid: PMC5850663. https://doi.org/10.1093/jme/tjx065

31. Chand G, Chaudhary NK, Soan V, Kaushal LS, Sharma RK, Singh N. Transmission dynamics and epidemiology of malaria in two tribal districts in Madhya Pradesh, India. Journal of Medical Research. 2015; 141(5):556-66.

32. Vatandoost H, Emami SN, Oshaghi MA, Abai MR, Raeisi A, Piazzak N, Mahmoodi M,Akbarzadeh K, Sartipi M. Ecology of malaria vector Anopheles culicifaciesin a malarious area of Sistanva Baluchestan province, south-east Islamic Republic of Iran. Eastern Mediterranean Health Journal. 2011; 17(3):439-45. 